\title{
Peningkatan Kemampuan Berbahasa (Berbicara) Anak Usia 3 - 4 Tahun Dengan Media Kartu Gambar
}

\author{
Kartini \\ KB Al-Furqon Makamhaji Sukoharjo \\ kartinijatmiko77@gmail.com
}

\begin{abstract}
This study aims to improve language (speaking) skills in KB Al Furqon Makambaji Kartasura children in the academic year 2020/2021 by implementing the use of images in learning (core activities). The research subjects who were given action were the children of KB Al Furqon Makambaji Kartasura, totaling 20 children, the subject of the action was the researcher (teacher). Methods of data collection using the method of observation, interviews, and documentation. The data analysis technique used is descriptive and comparative. The results showed that there was an increase in language (speaking) skills in children as seen from the increase in the average class starting from pre-cycle to cycle II, which included: Pre-cycle 31, 96\%, cycle I 62, 13\%, and cycle II 82, 67.\%. The conclusion of this study is that the application of the use of picture cards can improve the language skills (speaking) of children in the Alfurqon Makambaji Kartasura Play Group for the 2020/2021 Academic Year.
\end{abstract}

Keywords: ability; talking; image card media

\section{ABSTRAK}

Penelitian ini bertujuan untuk meningkatkan kemampuan Bahasa (Bicara) pada anak KB Al Furqon Makamhaji Kartasura Tahun Ajaran 2020/2021 dengan penerapan pengunaan gambar pada pembelajaran (kegiatan inti). Subjek penelitian yang diberi tindakan adalah anak-anak KB Al Furqon Makamhaji Kartasura yang berjumlah 20 anak, subjek pelaku tindakan adalah peneliti (guru). Metode pengumpulan data dengan menggunakan metode observasi, wawancara, dan dokumentasi. Teknik analisis data yang digunakan dengan menggunakan deskriptif dan komparatif. Hasil penelitian menunjukkan bahwa adanya peningkatan kemampuan bahasa ( bicara )pada anak yang dilihat dari peningkatan rata-rata kelas mulai dari prasiklus sampai siklus II, yang mencakup: Prasiklus 31, 96\%, siklus I 62, 13\%, dan siklus II 82, 67\%. Kesimpulan penelitian ini adalah bahwa penerapan pengunaan kartu gambar dapat meningkatkan kemampuan bahasa (bicara) anak Kelompok Bermain Al Furqon Makamhaji Kartasura Tahun Pelajaran 2020/2021.

Kata Kunci: kemampuan; berbicara; media kartu gambar

Submitted May 03, 2021 | Revised May 20, 2021 | Accepted May 24, 2021

\section{Pendahuluan}

Belajar merupakan kegiatan suatu proses pembelajaran yang ditandai adanya perubahan tingkah laku akibat dari pengalaman belajar (Hariyadi \& Darmuki, 2019: 281). Permasalahan dalam belajar sangat kompleks yang banyak dipengaruhi oleh berbagai faktor baik itu dari internal maupun dari eksternal diri peserta didik (Hidayati dkk., 2019). Faktor kompleks dari internal diri peserta didik seperti salah satunya adalah minat terhadap proses belajar mengajar di kelas (Darmuki dan Hariyadi, 2019). Minat adalah kekuatan mental yang mendorong adanya keinginan untuk mengarahkan sikap dan perilaku individu untuk aktif belajar (Darmuki dan Hidayati, 2019: 9). Faktor eksteral dari peserta didik seperti bahan materi, lingkungan belajar, sarana prasaran belajar dan lain-lain (Darmuki, 2020). Siswa sebagai subjek yang terlibat dalam kegiatan belajar mengajar akan mengalami suatu proses yang disebut belajar (Hidayati \& Darmuki, 2021). Proses belajar ini ditandai dengan dengan adanya keterlibatan fisik maupun psikis siswa di dalam pembelajaran yang terlihat dari keaktifannya di dalam kelas (Darmuki dkk., 2017; Darmuki dkk., 2018; Darmuki dkk. 2019; Darmuki dkk., 2021). Keaktifan pembelajaran ini terlihat dari keterlibatan fisik maupun mental siswa dalam proses pembelajaran. Menurut (Darmuki \& Hariyadi, 2019: 257), keaktifan yaitu suatu kegiatan/segala sesuatu yang menunjukkan adanya 
keterlibatan fisik maupun mental seseorang dalam aktivitas tertentu. Aktifitas belajar siswa ditandai dengan adanya minat belajar siswa (Hariyadi \& Darmuki, 2019).

Pengembangan Bahasa sangat tepat dilakukan pada saat usia atau masa kanak-kanak karena pada masa ini pertumbuhan dan perkembangan terjadi sangat pesat (Rusniah, 2017; Mardison, 2017; Pebriana, 2017). Pada masa ini banyak potensi yang berkembang, juga terjadi perkembangan fisik, intelektual, emosional hingga bahasa sehingga muncul istilah yang disebut The Golden Age, artinya masa keemasan. Masa ini terjadi pada kurun waktu usia nol sampai pra sekolah. Pada masa ini juga dibutuhkan perhatian yang ekstra karena segala keistimewaan ini tidak akan terulang hingga kedua kali. Pentingnya perhatian yang ekstra ini juga supaya segala potensi dan kemampuan anak dapat dikembangkan secara optimal.

Menurut Hurlock dalam Sobur (2003: 133), perkembangan awal lebih penting daripada perkembangan selanjutnya, karena dasar awal sangat dipengaruhi oleh belajar dan pengalaman. Perkembangan Bahasa untuk anak usia dini meliputi empat pengembangan yaitu menyimak, berbicara, membaca, dan menulis. Secara bertahap perkembangan bahasa anak akan terlihat dari melakukan ungkapan menjadi melakukan ungkapan untuk berkomunikasi, juga dari berkomunikasi melalui gerakan menjadi berkomunikasi melalui tutur kata. Pada sekitar usia 2 tahun, anak akan mulai menunjukkan kemampuannya dalam mengucapkan kata-kata atau nama dari benda-beda di sekitar yang menarik minatnya. Seiring waktu, perbendaharaan kata anak tersebut akan bertambah. Anak akan mampu berkomunikasi dengan baik melalui banyaknya kosa kata yang dimilikinya.

Merangsang potensi berbahasa anak dapat dilakukan dengan melakukan percakapan yang aktif dengan bahasa yang baik dan benar. Sangat berpengaruh sekali kualitas bahasa yang digunakan oleh orang-orang sekitar dalam proses peningkatan kemampuan berbahasa dan berbicara si anak. Jika diambil contoh pada Kelompok Bermain Al Furqon Makamhaji, yang berperan penting dalam menjaga kualitas bahasa adalah para guru yang mengajar. Karena di Kelompok bermain ini orang tua dilarang untuk mendampingi anak, maka tanggung jawab sepenuhnya ada di tangan para guru. Para guru juga harus mampu untuk mengupayakan berbagai kreatifitas dalam membuat media pembelajaran untuk mengembangkan kemampuan berbahasa anak.

Menurut pendapat Vygotsky dalam Ahmad Susanto (2012:73), bahasa merupakan media untuk mengungkapkan ide dan bertanya, bahasa juga menciptakan konsep dalam kategori-kategori berpikir. Selain itu bahasa juga merupakan sarana berkomunikasi yang sangat penting dalam kehidupan manusia, karena selain sebagai media untuk menyatakan pikiran dan perasaan kepada orang lain tetapi juga sebagai media untuk memahami perasaan dan pikiran orang lain. Salah satu keterampilan berbahasa yang penting dan sering digunakan dalam kehidupan seharih-hari yaitu keterampilan berbicara. Menurut Darmuki dkk. (2017) keterampilan berbicara adalah kemampuan seseorang untuk mengungkapkan ide, gagasan, atau informasi kepada orang lain dengan tujuan tertentu.

Karena sangat pentingnya pengembangan kemampuan berbahasa anak, Kelompok Taman Bermain Al Furqon Makamhaji menjadikan hal tersebut sebagai prioritas dan tujuan sekolah. Dalam hal ini tentu terdapat berbagai permasalahan yang sering muncul, dan menjadi hambatan yang teridentifikasi dalam pelaksanaan program mengajar. Permasalahan tersebut diataranya adalah : (1) ada kegiatan menyanyi hasil yang didapatkan masih kurang memuaskan; (2) Dalam kegiatan bercakap-cakap banyak anak yang masih pasif; (3) Dalam kegiatan kosa kata banyak anak yang kurang merespon; (4) Kemampuan berbicara anak yang masih perlu ditingkatkan.

Permasalahan keempat yakni kemampuan berbicara anak yang masih kurang merupakan permasalahan yang akan dipecahkan. Permasalahan ini dapat dibuktikan dari data kelas di Kelompok Bermain Al Furqon terdapat 20 siswa, dimana 7 siswa yang bisa aktif dalam kegiatan dan 16 sisanya mengalami permasalahan. Hal ini bisa disebabkan karena metode yang digunakan dalam belajar mengajar masih kurang tepat dan perlu diperbaharui kembali. Masalah kurangnya kemampuan anak dalam berbicara dapat diupayakan dengan menggunakan media kartu gambar, dengan menggunakan 
media kartu gambar sangat efektif dalam proses pembelajaran dan dapat meningkatkan kemampuan bahasa (bicara siswa). Beberapa penelitian sebelumnya telah dilakukan untuk meningkatkan kemampuan berbicara anak, diantaranya penelitian Aprinawati (2017) dengan menggunakan media gambar berseri, Penelitian yang dilakukan Anggraeni, Hartati, \& Nurani (2019) dengan menggunakan metode bercerita, penelitian yang dilakukan Septiyani \& Kurniah (2017) dengan menggunakan media big book, dan penelitian Fika, Meilanie \& Fridani (2019) melalui kegiatan bermain peran berbasis budaya. Dalam penelitian ini, solusi yang digunakan dalam meningkatkan kemampuan berbicara adalah dengan menggunakan media gambar.

Media gambar adalah segala sesuatu yang diwujudkan secara visual kedalam bentuk dua dimensi sebagai curahan ataupun pikiran yang bentuknya bermacam-macam seperti lukisan, potret, slide, film, strip, opaque projektor (Sudjana, 2011). Pemanfaatan media pembelajaran ada dalam komponen metode mengajar sebagai salah satu upaya untuk mempertinggi proses interaksi guru-siswa dan interaksi siswa dengan lingkungan belajarnya (Hamalik, 2014). Oleh sebab itu fungsi utama dari media pembelajaran adalah sebagai alat bantu mengajar, yakni menunjang penggunaan metode mengajar yang dipergunakan guru (Zaman \& Hermawan, 2016). Melalui penggunaan media pembelajaran diharapkan dapat mempertinggi kualitas proses belajar-mengajar yang pada akhirnya dapat mempengaruhi kualitas hasil belajar siswa.

\section{Metode Penelitian}

Penelitian ini dilaksanakan di Kelompok Bermain (KB) Al Furqon Makamhaji Kartasura Tahun Ajaran 2020/2021. Waktu penelitian dilaksanakan pada akhir semester I dan awal semester II, yaitu bulan Oktober 2020 sampai bulan Februari 2021. Penelitian ini termasuk dalam penelitian tindakan kelas (PTK). Beberapa tahapan dalam penelitian ini meliputi tahap persiapan, kemudian tahap pelaksanaan penelitian, dan terakhir terdapat tahap analisis data dan penyusunan laporan penelitian. Subyek penelitian ini adalah anak Kelompok Bermain Al Furqon Makamhaji. Anak kelas tersebut berjumlah 20 anak, yang terdiri dari 7 laki-laki dan 13 perempuan. Mereka merupakan anak-anak yang sangat membutuhkan stimulasi dalam bahasa. Guru dalam hal ini bertindak sebagai peneliti.

Prosedur penelitian adalah suatu rangkaian tahap-tahap penelitian dari awal sampai akhir. Prosedur Penelitian Tindakan Kelas (PTK) menurut Arikunto dalam Sumanti (2011:51) mencakup tahap-tahap : "perencanaan, pelaksanaan, pengamatan, dan refleksi". Keempat tahap tersebut saling terkait dan secara urut membentuk sebuah siklus. Penelitian Tindakan Kelas merupakan penelitian yang bersiklus. Artinya penelitian dilakukan secara berulang dan berkelanjutan sampai tujuan penelitian dapat tercapai, apabila dalam satu siklus belum berhasil maka dilanjutkan ke siklus berikutnya sampai mencapai target.

Di dalam suatu penelitian, alat pengumpulan data akan menentukan kualitas dari sebuah penelitian. Sedangkan langkah pengumpulan data merupakan langkah yang paling utama dalam penelitian, karena tujuan utama dari penelitian adalah untuk mendapatkan data. Dengan tujuan mendapatkan data yang valid, maka Teknik pengumpulan data yang diperlukan disini adalah teknik pengumpulan data yang sesuai dan tepat. Kesalahan dalam pengumpulan data saat melakukan penelitian akan mempengaruhi dan berakibat pada proses dan hasil penelitian. Teknik pengumpulan data yang digunakan dalam penelitian ini adalah obsevasi / pengamatan dan dokumentasi.

Penelitian ini menggunakan teknik analisis data yaitu dengan menganalisis secara deskriptif dan komparatif. Pengertiannya menurut Suharsimi Arikunto dan Sumanti (2011:49), analisis deskriptif merupakan proses analisa data kuantitatif yang berupa nilai dari hasil belajar siswa. Teknik ini dapat digunakan dalam pengolahan data yang berkaitan dengan menjumlahkan, merata-rata, mencari persentase, dan menyajikan data secara menarik, mudah dipahami dan diikuti alur berfikirnya (berupa tabel dan grafik). 


\section{Hasil dan Pembahasan}

Penelitian Tindakan Kelas (PTK) yang dilaksanakan pada anak KB Alfurqon Makamhaji Kartasura Tahun Ajaran 2020/2021 terdiri dari dua putaran (siklus) penelitian. Deskripsi tentang hasil penelitian dari putaran (siklus) I sampai dengan putaran (siklus II) dapat dijelaskan sebagai berikut:

Sebelum melaksanakan tindakan siklus I, peneliti melakukan dialog awal dan observasi awal dengan guru kelas. Tindakan ini diperlukan untuk mengetahui kondisi awal sebelum tindakan sehingga peneliti dapat mengukur sejauh mana tingkat keberhasilan penelitian tindakan kelas ini. Hasil observasi awal sebelum adanya penerapan kegiatan menggunakan kartu gambar dalam mengembangkan kemampuan bahasa (bicara) persentase rata-rata kelas adalah 31, 96\%. Dengan demikian dapat diartikan bahwa kemampuan berbicara anak belum terlatih dengan baik. Keadaan yang demikian menjadi alasan diadakannya tindakan untuk meningkatkan kemampuan berbicara anak.

Pada siklus I, saat kegiatan berbicara anak-anak diberi penjelasan terlebih dahulu apa yang akan dilakukan dengan gambar tersebut. Penulis memperlihatkan gambar dan mengajak anak bercakapcakap mengenai gambar tersebut. Selanjutnya penulis menjelaskan kepada anak kegiatan yang akan dilakukan yaitu setiap anak diberi tugas untuk berbicara mengenai gambar yang dipersiapkan kepada teman sekelompoknya. Penulis memberi contoh berbicara sesuai dengan gambar. Penulis kemudian membagi tiga gambar untuk tiga kelompok. Setiap kelompok mendapat gambar yang berbeda. Selanjutnya setiap anak secara bergantian memegang gambar sambil berbicara mengenai gambar yang dipegang kepada teman sekelompok. Selanjutnya, Penulis memberi kesempatan kepada anak untuk berbicara mengenai gambar di depan teman sekelas.

Dari hasil observasi, peningkatan kemampuan bahasa dengan media kartu gambar dilaksanakan pada siklus I, ada perkembangan hasilnya adalah 62,13\%. Berdasarkan hasil observasi siklus I, hasilnya belum optimal dan belum mencapai target yang telah ditentukan oleh peneliti. Terdapat beberapa masalah yang dihadapi pada pembelajaran Siklus I, antara lain: (1) Media gambar yang digunakan masih belum menarik perhatian bagi beberapa anak karena gambar masih buatan peneliti sendiri. Hal ini menyebabkan anak kurang maksimal dalam mengikuti kegiatan berbicara. (2) Alokasi waktu dinilai terlalu cepat yaitu 30 menit, sehingga pembelajaran terkesan tergesa-gesa dan beberapa anak masih belum mempunyai kesempatan untuk berbicara. (3) Pada waktu anak berbicara dalam kelompoknya, terlihat masih ada beberapa anak yang membuat kegaduhan dengan berbicara sendiri dengan teman sebelahnya, sehingga anak yang sedang berbicara menjadi terganggu. Hal ini terjadi dikarenakan suara anak yang terlalu lirih dalam berbicara sehingga membuat anak lain tidak fokus dan memperhatikan. Berdasarkan hasil refleksi yang dilakukan pada tindakan Siklus I dapat diketahui bahwa peningkatan kemampuan berbicara anak belum mencapai keberhasilan yang diharapkan. Oleh karena itu, kegiatan berbicara menggunakan media gambar perlu dilanjutkan pada tindakan Siklus II dalam upaya meningkatkan kemampuan berbicara anak.

Pada siklus II, Penulis menyusun kembali rencana langkah-langkah perbaikan untuk pelaksanaan kegiatan berbicara dengan media gambar pada Siklus II. Langkah-langkah perbaikan yang akan dilaksanakan pada Siklus II adalah (1) Media gambar yang digunakan diubah penampilannya agar lebih menarik perhatian anak-anak. Penulis mencari gambar-gambar di internet serta mendownload gambar yang menarik agar sesuai dengan tema yang akan digunakan. (2) Pelaksanaan pembelajaran berbicara diperpanjang alokasi waktunya dari 30 menit menjadi 45 menit, supaya semua anak mendapat kesempatan dalam berbicara. (3) Penulis membagi kelompok dengan memindahkan anak yang sering membuat kegaduhan dengan anak yang cenderung pendiam menjadi satu kelompok, dengan harapan anak dapat lebih tertib dan berkonsentrasi pada teman yang sedang berbicara.

Pelaksanaan tindakan Siklus II masih dilakukan pada kegiatan awal proses pembelajaran, hanya alokasi waktunya ditambah. Setelah berbaris dan berdoa, anak masuk kelas dan duduk di kelompok yang telah dirubah oleh peneliti. Selanjutnya peneliti memberikan penjelasan tentang kegiatan yang 
akan dilakukan serta memberi motivasi supaya anak-anak menjadi lebih bersemangat dalam mengikuti kegiatan berbicara dengan media gambar. Pelaksanaan kegiatan Siklus II dilaksanakan dalam tiga kali pertemuan dimana peneliti terlebih dahulu menyiapkan Rencana Kegiatan Harian (RKH) yaitu kegiatan berbicara menurut gambar.

Berdasarkan hasil evaluasi seluruh kegiatan berbicara dengan media gambar sudah mendapatkan hasil yang sangat memuaskan. Anak-anak mengikuti kegiatan berbicara dengan media gambar dari awal sampai akhir dengan penuh antusias dan semangat. Anak-anak juga menyampaikan keinginannya untuk kembali melakukan kegiatan berbicara dengan gambar dipertemuan selanjutnya. Namun masih ada beberapa anak yang belum memenuhi kriteria baik.

Pada saat perbaikan dilakukan di Siklus II, peningkatan kemampuan berbicara dengan media gambar mengalami peningkatan yang sangat signifikan dan sudah mencapai tingkat keberhasilan yang ditetapkan. Setelah rancangan tindakan diperbaiki peneliti melaksankan tindakan siklus II dengan menerapkan penggunaan media kartu gambar Berdasarkan hasil pelaksanaan siklus II ada peningkatan kemampuan bahasa anak yaitu 82, 67\%. Hal tersebut sesuai dengan hasil yang ditargetkan oleh peneliti.

Hasil kegiatan berbicara melalui media gambar, kemampuan berbicara anak dapat dikatakan meningkat dengan baik. Hal ini sesuai dalam pendapat (Haryadi dan Zamzani, 1997) bahwa berbicara diartikan suatu penyampaian maksud seseorang kepada orang lain dengan menggunakan bahasa lisan sehingga maksud tersebut dapat dipahami oleh orang lain. Kegiatan yang digunakan untuk menstimulasi kemampuan berbicara adalah berbicara melalui media gambar. Hal ini sesuai dengan pendapat Dale (Djuanda, 2006) yang menyatakan bahwa gambar dapat mengalihkan pengalaman belajar dari taraf belajar dengan lambang kata-kata ke taraf yang lebih konkret. Keberhasilan lain yang didapat dicapai selain berdasarkan hasil yang telah didapat yaitu melalui catatan lapangan. Dalam catatan lapangan dapat terlihat bahwa melalui kegiatan berbicara dengan media gambar bisa membawa suasana baru yang menggembirakan sehingga anak-anak menjadi antusias mengikuti kegiatan tanpa paksaan. Menurut Suyanto (2005: 127) pembelajaran anak usia dini menggunakan prinsip belajar, bermain, dan bernyanyi. Pembelajaran yang disajikan sebaiknya menyenangkan, menggembirakan dan demokratis sehingga anak tidak hanya mendengarkan guru ceramah melainkan anak juga dapat berinteraksi dengan semua yang ada di sekitarnya baik dengan benda maupun orang di lingkungannya. Pada penelitian ini, disetiap akhir pembelajaran anak-anak selalu ingin mengulangi kegiatan berbicara dengan media gambar. Secara umum hasil pelaksanaan dari prasiklus sampai siklus II dapat disimpulkam bahwa melalui penerapan penggunaan kartu gambar dapat meningkatkan kemampuan bahas (bicara) anak KB Alfurqon Makamhaji Kartasura Tahun Ajaran 2020/2021.

\section{Kesimpulan}

Hasil penelitian tindakan kelas yang dilakukan peneliti bekerjasama dengan guru kelas $\mathrm{KB} \mathrm{Al}$ Furqon Makamhaji Kartasura 2020/2021 dapat disimpulkan bahwa, penerapan pengunaan media kartu gambar dapat meningkatkan kemampuan bahasa (bicara) anak KB Al Furqon Makamhaji Kartasura 2020/2021. Hal ini dapat dilihat dari peningkatan presentasi rata-rata kelas setiap siklus. Hasil dari prasiklus adalah 31, 96\% ini dapat dilihat bahwa indikator pencapaian yang ditargetkan oleh peneliti masih sangat rendah. Hasil dari siklus I adalah 62, 13\%. Berdasarkan hasil rata-rata kelas siklus I sudah ada perkembangan atau peningkatan, tetapi belum mencapai target peneliti. Hasil dari siklus II adalah $82,67 \%$. Siklus II hasilnya sudah berkembang pesat sehingga sudah mencapai target peneliti yaitu $80 \%$. Melalui penggunaan media kartu gambar dapat mengembangkan bahasa anak, interaksi sosial anak, kesabaran anak, dan anak mampu menghargai pendapat (ide) orang lain.

\section{Daftar Pustaka}


Anggraeni, D., Hartati, S., \& Nurani, Y. (2019). Implementasi metode bercerita dan harga diri dalam meningkatkan kemampuan berbicara anak usia dini. Jurnal Obsesi: Jurnal Pendidikan Anak. Usia Dini, 3(2), 404-415.

Aprinawati, I. (2017). Penggunaan media gambar seri untuk meningkatkan kemampuan berbicara anak usia dini. Jurnal Obsesi: Jurnal Pendidikan Anak Usia Dini, 1(1), 72-80.

Asmani, Jamal Ma’ruf. 2011. Penelitian Tindakan Kelas. Jogjakarta : Laksana.

Darmuki, Agus. (2020). Upaya Meningkatkan Kemampuan Berbicara Mahasiswa Menggunakan Media Aplikasi Google Meet Berbasis Unggah Tugas Video Di Youtube Pada Masa Pandemi Covid-19. Jurnal Educatio FKIP UNMA, Vol 6(2),655-661.

Darmuki, A. \& Ahmad Hariyadi. (2019). Eksperimentasi Model Pembelajaran Jucama Ditinjau Dari Gaya Belajar Terhadap Prestasi Belajar Mahasiswa Mata Kuliah Berbicara Di Prodi PBSI IKIP PGRI Bojonegoro. Kredo. 3(1), 62-72.

Darmuki, A., Ahmad Hariyadi. (2019). Peningkatan Keterampilan Berbicara Menggunakan Metode Kooperatif Tipe Jigsaw pada Mahasiswa PBSI Tingkat IB IKIP PGRI Bojonegoro Tahun Akademik 2018/2019. Kredo. 2(2), 256-267.

Darmuki, A. \& Hidayati N.A. (2019). An Investigation of The Cooperative Learning Using Audio Visual Media in Speaking Skill Subject. ICSTI. 121-126.

Darmuki, A. \& Hidayati, N.A. (2019). Peningkatan Kemampuan Berbicara Menggunakan Metode Kooperatif Tipe NHT pada Mahasiswa Tingkat I-A Prodi PBSI IKIP PGRI Bojonegoro Tahun Akademik 2018/2019. Jurnal Pendidikan Edutama. Vol. 6(2), hlm 9-18.

Darmuki, A., Andayani, A., Nurkamto, J., \& Saddhono, K. (2018). Cooperative, Synectics, and CTL Learning Models toward Speaking Ability Viewed from Student's Motivation. In 1st International Conference on Intellectuals' Global Responsibility (ICIGR 2017). pp. 75-79. Atlantis Press.

Darmuki, A., Andayani, A., Nurkamto, J., \& Saddhono, K. (2017). Evaluating informationprocessing-based learning cooperative model on speaking skill course. Journal of Language Teaching and Research, 8(1), 44-51.

Darmuki, A., Andayani, A., Nurkamto, J., \& Saddhono, K. (2018). The development and evaluation of speaking learning model by cooperative approach. International Journal of Instruction, 11(2), $115-128$.

Darmuki, A., Hariyadi, A., \& Hidayati, N. A. (2020). Peningkatan Minat Dan Hasil Belajar Keterampilan Berbicara Menggunakan Metode Mind Map Pada Mahasiswa Kelas Ia PBSI IKIP PGRI Bojonegoro Tahun Akademik 2019/2020. Kredo: Jurnal Ilmiah Bahasa dan Sastra, 3(2), 263276.

Darmuki, A., Hariyadi, A., \& Hidayati, N. A. (2021). Peningkatan Kemampuan Menulis Karya Ilmiah Menggunakan Media Video Faststone di Masa Pandemi COVID-19. Jurnal Educatio FKIP UNMA, 7(2), 389-397.

Djamarah. (2002). Strategi Belajar Mengajar. Jakarta : Rineka Cipta.

Djuanda, D. (2006). Pembelajaran Bahasa Indonesia yang Komunikatif dan Menyenangkan. Jakarta: Departemen Pendidikan Nasional, Direktorat Jenderal Pendidikan Tinggi, Direktorat Ketenagaan.

Fika, Y., Meilanie, S. M., \& Fridani, L. (2019). Peningkatan Kemampuan Bicara Anak melalui Bermain Peran Berbasis Budaya. Jurnal Obsesi: Jurnal Pendidikan Anak Usia Dini, 4(1), 50-57.

Hamalik, O. (2014). Media Pendidikan . Bandung : Citra Aditya Bakti.

Haryadi \& Zamzani. (1997). Peningkatan Keterampilan Berbahasa Indonesia. Jakarta: Departemen Pendidikan dan Kebudayaan, Direktorat Jenderal Pendidikan Tinggi, Bagian Proyek Pengembangan Pendidikan Guru Sekolah Dasar. 
Hariyadi, A., Darmuki, A. (2019). Prestasi dan Motivasi Belajar dengan Konsep Diri. Prosiding Seminar Nasional Penguatan Muatan Lokal Bahasa Daerah sebagai Pondasi Pendidikan Karakter Generasi Milenial. PGSD UMK 2019, 280-286.

Hidayati, N. A., \& Darmuki, A. (2021). Penerapan Model Auditory Intellectually Repetition (AIR) untuk Meningkatkan Kemampuan Berbicara Pada Mahasiswa .Jurnal Educatio FKIP UNMA, 7(1), 252-259.

Hidayati NA., H J. Waluyo, R. Winarni, Suyitno. (2019). Meanings and Values of Local Wisdom in Sura Salvation Ceremony of Samin Jepang Community, Indonesia for Audio Visual TechnologyBased Learning. EUDL. http:/ /dx.doi.org/10.4108/ eai.19-10-2018.2282549

Iskandar. (2011). Penelitian Tindakan Kelas. Jakarta : GP Press.

Mardison, S. (2017). Perkembangan Bahasa Anak Usia Sekolah Dasar/Madrasah Ibtidaiyah (SD/MI). Tarbiyah al-Awlad, 7(2).

Pebriana, P. H. (2017). Analisis kemampuan berbahasa dan penanaman moral pada anak usia dini melalui metode mendongeng. Jurnal Obsesi: Jurnal Pendidikan Anak Usia Dini, 1(2), 139-147.

Rasyid Harun, dkk. (2009). Asesmen Perkembangan Anak Usia Dini. Yogyakarta : Multi Pessindo.

Rusniah, R. (2017). Meningkatkan perkembangan bahasa indonesia anak usia dini melalui penggunaan metode bercerita pada kelompok A di TK Malahayati Neuhen tahun pelajaran 2015/2016. Jurnal Edukasi: Jurnal Bimbingan Konseling, 3(1), 114-130.

Sanjaya, W. (2008). Perencanaan Pengajaran. Jakarta : PT. Rieka Cipta.

Septiyani, S., \& Kurniah, N. (2017). Pengaruh media big book terhadap kemampuan berbicara pada anak usia dini. Jurnal Ilmiah Potensia, 2(1), 47-56.

Sudjana. (2011). Media Pengajaran. Bandung: Sinar Baru Algensindo.

Slamet Suyanto. (2005). Dasar-dasar Pendidikan Anak Usia Dini. Yogyakarta: Hikayat Publising.

Winataputra, Udin.S. (2004). Strategi Belajar Mengajar, (cet. 14). Jakarta : Universitas Terbuka.

Zaman Badru, Asep Heri Hernawan. (2016). Media dan Sumber Belajar PAUD, (Rev. ed). Jakarta : Universitas Terbuka. 